\title{
Optimization of the HS-SPME Technique by using Response Surface Methodology for Evaluating Chlorine Disinfection by-Products by GC in Drinking Water
}

\author{
Mauricio Aguirre-González, ${ }^{a}$ Gonzalo Taborda-Ocampo, ${ }^{a}$ Carmen Dussan-Lubert, ${ }^{b}$ \\ Cristina Nerin ${ }^{c}$ and Milton Rosero-Moreano*,a,c
}

${ }^{a}$ Chemistry Department and ${ }^{b}$ Mathematical Department, University of Caldas, Calle 65 N. 26-10, A. A. 265, Caldas, Colombia

'Department of Analytical Chemistry, Aragon Institute of Engineering Research I3A, EINA, Campus Río Ebro, University of Zaragoza, Torres Quevedo Building, Maria de Luna St. 3, 50018 Zaragoza, Spain

\begin{abstract}
Neste trabalho são descritos os resultados da otimização da técnica de microextração em fase sólida acoplada ao headspace e detecção por cromatografia gasosa com detector de microcaptura de elétrons (HS-SPME/GC- $\mu$ ECD). A melhor condição de extração para os quatro trihalometanos em água potável foi conseguida através de um estudo da metodologia de superfície de resposta, usando um planejamento fatorial composto $2^{5}$. Cinco variáveis influentes tais como o tipo de fibra, temperatura de extração e de dessorção e tempo de extração e de dessorção foram avaliadas. As variávies que exerceram maior influência na técnica HS-SPME foram a temperatura de extração e os tempos de dessorção e extração. O tipo de fibra e a temperatura de dessorção foram menos influentes na eficiência da extração. As melhores condições de extração foram obtidas quando empregou-se a fibra de carboxeno / polidimetilsiloxano (CAR/PDMS) de $75 \mu \mathrm{m}$, temperatura de dessorção $250{ }^{\circ} \mathrm{C}$, de extração $37,5^{\circ} \mathrm{C}$, tempo de extração 30 min e de dessorção 4 min.
\end{abstract}

In this work the results of the optimization of headspace solid phase microextraction technique and determination by gas chromatography with micro electron capture detector (HS-SPME/GC- $\mu E C D$ ) are described. The best condition of extraction for the four trihalomethanes in drinking water was reached through a response surface methodology's study using a composite $2^{5}$ factorial design. Five experimental conditions of influence such as the type of fiber, extraction and desorption temperatures and extraction and desorption times were evaluated. The most influential factors in the technique of HS-SPME were the extraction temperature and extraction and desorption times. The type of fiber and the desorption temperature had little influence on extraction's efficiency. The best conditions were obtained with a fiber carboxen/polidimetilsiloxane (CAR/PDMS) of $75 \mu \mathrm{m}$, desorption temperature $250^{\circ} \mathrm{C}$, extraction temperature $37.5^{\circ} \mathrm{C}$, extraction time $30 \mathrm{~min}$ and a desorption time $4 \mathrm{~min}$.

Keywords: gas chromatography- $\mu \mathrm{ECD}$, surface response methodology, solid phase microextraction, trihalomethanes, drinking water

\section{Introduction}

The disinfection of water has been conducted regularly since the early twentieth century to remove and deactivate pathogens in drinking water. In addition to removing pathogens, disinfectants also act as oxidants. They are also used to remove the taste and color, oxidized $\mathrm{Fe}$ and $\mathrm{Mn}$, preventing the resurgence of biological elements in the water distribution system, improve the efficiency

*e-mail: milton.rosero@ucaldas.edu.co of coagulation and filtration and prevent growth of algae in sedimentation tanks and filters. ${ }^{1}$ A disinfectant predominantly used in water treatment is chlorine and its compounds. Its widespread use is not only due to its low cost, but also to its oxidizing capacity, which provides a minimum level of residual chlorine in the distribution system and thereby protects the pipes in drinking water distribution networks against microbial recontamination. ${ }^{2}$ Chlorination for drinking water started in New Jersey (USA) in 1908 and has remained in force, as it is the most widely used process for cost reasons. ${ }^{3}$ One of the 
disadvantages in the treatment of surface water with chlorine is related to the reaction of the disinfectant with organic matter in natural waters, promoting the formation of substances classified as disinfection by-products, in which the two main groups during the chlorination process are haloacetic acids (HAAs) and trihalomethanes (THMs). Of all the natural organic matter (MON), only the fraction of dissolved organic matter, where humic substances are divided as humic and fulvic acids, has been recognized as the precursor of disinfection byproducts during water treatment with chlorine. ${ }^{4}$ The wide variety of organic macromolecules found in aquatic environments, especially refractory substances such as humic acids, are located largely in the dissolved organic matter (DOM), mainly due to the low biodegradability of these materials in aquatic environments. ${ }^{5,6}$ Rook $^{7}$ proposed a mechanism for the formation of THMs from resorcinol-type molecules (Figure 1). Oxidation by hypochlorous acid ( $\mathrm{HOCl}$ ) allows halogenation of aromatic ring. Then, a fracture of the molecule (a in Figure 1) forms trihalomethanes. The split by the insertion of an hydroxide (in b) allows the formation of an haloacetic acid while a third fracture (in c) produces haloketones. $^{2}$
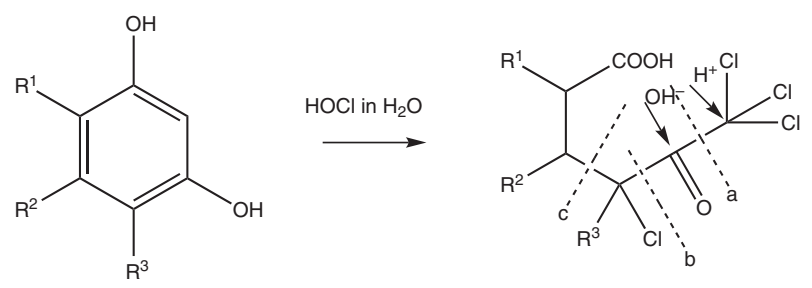

Figure 1. Mechanism of THMs's formation.

Several studies have established the relationship between the exposure to THM compounds and the generation of cancer, classifying the four trihalomethanes as probable $\left(\mathrm{CHCl}_{3}, \mathrm{CHCl}_{2} \mathrm{Br}\right.$ and $\left.\mathrm{CHBr}_{3}\right)$ and possible $\left(\mathrm{CHClBr}_{2}\right)$ human carcinogens. ${ }^{8}$ Therefore, strategies for continued monitoring and determination of these compounds for human exposure have been developed.

THMs concentrations found in natural and human consumption water are about the order of $n g \mathrm{~L}^{-1}$ to $\mu \mathrm{L} \mathrm{L}^{-1}$. For this reason a very sensitive analytical procedure is required. Several methods have been reported for extraction and preconcentration of samples for the determination of THMs, such as liquid-liquid extraction with $n$-pentane or $n$-hexane(LLE) ${ }^{9-13}$ headspace (HS) techniques as static methods (HS-GC), ${ }^{10,13-17}$ and dynamic headspace purge and trap, ${ }^{10,13,18-25}$ solid phase extraction (SPE) ${ }^{26}$ and solid phase microextraction (SPME), which has been widely used for the determination of these analytes using headspace (HSSPME). ${ }^{23,27-36}$ Apart from the techniques of preparation and concentration of samples, these volatile compounds are separated by gas chromatography using capillary columns of medium polarity, followed by electron capture detector (ECD), micro-electron capture ( $\mu$-ECD), ${ }^{34}$ mass detector (MSD) or inductively coupled plasma-mass spectrometry (ICP-MS). ${ }^{37}$ The HS-SPME has great advantages such as sample extraction and preconcentration as its implementation is fast, simple, provides high sensitivity, is free of organic solvents and reusable and does not require great expense. This technique is based on the extraction of analytes from the sample matrix using a fused silica capilary fiber coated with a sorbent, in most cases a polymer, followed by thermal desorption of the analytes. The sensitivity of this technique largely depends on the type of fiber selected for the analysis. In addition to the type of fiber, there are other parameters that affect the extraction of the analytes and must be optimized, such as the volume of headspace, the addition of salt, ${ }^{30,34,35}$ stirring of the sample, ${ }^{23,27}$ extraction and desorption time and extraction and desorption temperatures. ${ }^{34}$ One of the tools that have brought significant benefits when optimizing analytical processes in which several variables simultaneously affect the analysis, is the experimental design based on factorial design and response surface methodology. ${ }^{4,34,35,38-41}$

The aim of this work was to optimize the conditions of the HS-SPME technique such as fiber type, extraction and desorption temperatures and extraction and desorption times for the assessment of THMs in drinking water samples through GC- $\mu$ ECD using a $2^{5}$ factorial design and response surface methodology.

\section{Experimental}

\section{Reagents and equipments}

A standard mixture of THMs (chloroform, bromodichloromethane, dibromochloromethane and bromoform) from Supelco with a concentration of $2000 \mu \mathrm{g} \mathrm{mL} L^{-1}$ was used as stock solution and a $200 \mu \mathrm{g} \mathrm{L}^{-1}$ standard work solution was prepared from it with chromatographic grade methanol. Working solutions were prepared in $4 \mathrm{~mL}$ vials with PTFE perforated cover filled with the THMs standard mixture up to $50 \%$ of the total volume capacity of the vial and a $25 \%$ of sodium chloride solution was added. A magnet for constant stirring was also added. Three types of fibers, polydimethylsiloxane (PDMS $100 \mu \mathrm{m}$ ) or red fiber, polydimethyl siloxane/divinylbenzene (PDMS/DVB $65 \mu \mathrm{m}$ ) or blue fiber and carboxen/ polydimethyl siloxane (CAR/PDMS $75 \mu \mathrm{m}$ ) or black fiber were used from Supelco. These fibers were conditioned according to the manufacturer's recommendations. 
For separation and identification of THMs a Hewlett Packard gas chromatograph 6890, equipped with a detector of microelectron capture $(\mu \mathrm{ECD})$ and a AT1701 capillary column (30 m long, $0.53 \mathrm{~mm}$ ID, $1.0 \mu \mathrm{m}$ thick stationary phase of 7\% cyanopropyl, $7 \%$ phenyl methyl siloxane) was used. The chromatographic conditions are shown in Table 1.

Table 1. GC conditions

\begin{tabular}{|c|c|}
\hline Parameters & Setting characteristics \\
\hline Autosampler & Manual injection \\
\hline Analytical column & $\begin{array}{l}\text { AT1701 } 30 \mathrm{~m} \times 0.53 \mathrm{~mm} \times 1.0 \mu \mathrm{m} ; 7 \% \\
\text { cyanopropyl-7\% phenyl-methyl-siloxane }\end{array}$ \\
\hline $\begin{array}{l}\text { Carrier gas } \\
\text { Flow rate }\end{array}$ & $\begin{array}{l}\text { Nitrogen }(99.99 \%) \\
1.5 \mathrm{~mL} \mathrm{~min}^{-1}\end{array}$ \\
\hline Make up gas & $\mathrm{Ar}-\mathrm{CH}_{4} 60 \mathrm{~mL} \mathrm{~min}-1$ \\
\hline $\begin{array}{l}\text { Injector } \\
\text { Temperature }\end{array}$ & $\begin{array}{l}\text { Split/splitless ID } 4 \mathrm{~mm} \text { volume } 990 \mu \mathrm{L} \\
250^{\circ} \mathrm{C}^{\mathrm{a}} \text { split mode } 25: 1\end{array}$ \\
\hline Oven & $\begin{array}{l}50^{\circ} \mathrm{C} \text { during } 2 \text { min to } 110^{\circ} \mathrm{C} \text { at } 10^{\circ} \mathrm{C} \mathrm{min}-1 \text { stand } \\
\text { up } 10 \mathrm{~min} \text {; post run at } 200^{\circ} \mathrm{C} \text { during } 2 \mathrm{~min} \text { (run } \\
\text { time } 18 \mathrm{~min} \text { ) }\end{array}$ \\
\hline Detector & $\mu \mathrm{ECD} 280^{\circ} \mathrm{C}$ \\
\hline
\end{tabular}

${ }^{\mathrm{a}}$ Optimized condition that correspond to the desorption temperature.

\section{Experimental design DOE}

For the evaluation of the variables $2 \mathrm{~mL}$ of standard work solution with the mixture of THMs were taken, and transferred to a $4 \mathrm{~mL}$ vial containing sodium chloride. Table 2 illustrates the five factors and their levels of study used. Each factor is assigned to a control center value, from which the upper and lower levels are derived. Composite design and the results were evaluated by means of Statgraphics Plus 5.1. For the five factors a composite $2^{5}$ factorial design with a replica was used. As shown in the Table 3 from run 34 to 38 for fiber type that corresponds to the steepest ascendent way to reach the optimum and

Table 2. Control factors for the HS-SPME technique with superior, inferior and center levels

\begin{tabular}{llccc}
\hline & Factors & \multicolumn{3}{c}{ Levels } \\
\cline { 3 - 5 } & & low $(-1)$ & center $(0)$ & hig $(+1)$ \\
\hline $\mathrm{X}_{1}$ & Extraction Temperature $/{ }^{\circ} \mathrm{C}$ & 30 & 37.5 & 45 \\
$\mathrm{X}_{2}$ & Extraction time / min & 20 & 30 & 40 \\
$\mathrm{X}_{3}$ & Desorption Temperature $/{ }^{\circ} \mathrm{C}$ & 200 & 250 & 300 \\
$\mathrm{X}_{4}$ & Desorption time / min & 2 & 4 & 6 \\
$\mathrm{X}_{5}$ & Fiber type $^{\mathrm{b}}$ & red & black & blue \\
\hline
\end{tabular}

${ }^{\text {aDesorption temperature means the programmed injector temperature. }}$ ${ }^{\mathrm{b}} \mathrm{Red}$ : polydimethylsiloxane (PDMS) of $100 \mu \mathrm{m}$; black: carboxen/ polydimethylsiloxane (carboxen/PDMS) of $75 \mu \mathrm{m}$; blue: polydimethylsiloxane/divinylbenzene (PDMS/DVB) of $65 \mu \mathrm{m}$. neighbourhood, the model of RSM suggests to test a more polar fiber than the PDMS-DVB but in these four cases was decided to repeat the analysis with the same fiber, the most polar disposable fiber in our laboratory.

\section{Results and Discussion}

\section{Correlation between control factors}

By applying the analysis of variance to assess the significance of the model obtained, i.e., the statistical incidence of the control factors, both main and cross interactions, the control factors found in the design have an effect on the extraction technique because their p-value was significant (less 0.05 ) at a significance level of 5\%.

Figures 2 and 3 show the effect of five factors to study the response in the extraction efficiency of analytes, which shows that the factors such as desorption and extraction time, extraction temperature and at lesser degree, the fiber type used, have a decisive influence on the response. For the desorption temperature, the slope shows a negative behavior against the expected response by the extraction technique, i.e., there is an inverse relationship between the efficiency of extraction and desorption temperature, which may be caused by the volatility of THMs.

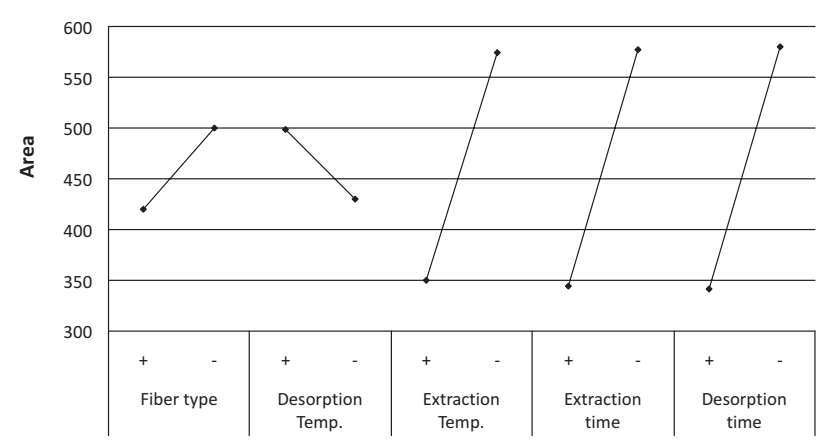

Figure 2. Plot of main effects in control factors for the HS-SPME technique for analyzing THMs in drinking water.

Figure 3 also helps in analyzing the behavior of the interactions and shows the statistical significance of factor controls in the HS-SPME. The interactions between extraction temperature-extraction time, extraction temperature-desorption time, extraction time-desorption time are statistically significant in the extraction efficiency's response for determining THMs in drinking water for our case. Therefore, it is assumed that the technique of HS-SPME is largely influenced by the values that are selected for the parameters of the extraction temperature, extraction time, desorption time and fiber type to be employed. However, the values of desorption time up to six min do not produce significant effect on the 
Table 3. Composite design $2^{5}$ for studying the effects of the variables in the analysis of THMs by HS-SPME-GC- $\mu$ ECD

\begin{tabular}{|c|c|c|c|c|c|c|c|c|c|c|c|}
\hline \multirow[b]{2}{*}{ Run } & \multicolumn{5}{|c|}{ Natural control factors } & \multicolumn{5}{|c|}{ Codified factors } & \multirow[b]{2}{*}{ Design } \\
\hline & $\begin{array}{c}\text { Extraction } \\
\text { Temperature } /{ }^{\circ} \mathrm{C}\end{array}$ & $\begin{array}{l}\text { Extraction } \\
\text { time / min }\end{array}$ & $\begin{array}{c}\text { Desorption } \\
\text { time / min }\end{array}$ & $\begin{array}{c}\text { Desorption } \\
\text { Temperature } /{ }^{\circ} \mathrm{C}\end{array}$ & $\begin{array}{l}\text { Fiber } \\
\text { type }^{\mathrm{a}}\end{array}$ & $\mathrm{X}_{1}$ & $\mathrm{X}_{2}$ & $\mathrm{X}_{3}$ & $\mathrm{X}_{4}$ & $\mathrm{X}_{5}$ & \\
\hline 1 & 30 & 20 & 2 & 200 & Red & -1 & -1 & -1 & -1 & -1 & Factorial \\
\hline 2 & 30 & 20 & 2 & 200 & Blue & -1 & -1 & -1 & -1 & 1 & \\
\hline 3 & 30 & 20 & 2 & 300 & Red & -1 & -1 & -1 & 1 & -1 & \\
\hline 4 & 30 & 20 & 2 & 300 & Blue & -1 & -1 & -1 & 1 & 1 & \\
\hline 5 & 30 & 20 & 6 & 200 & Red & -1 & -1 & 1 & -1 & -1 & \\
\hline 6 & 30 & 20 & 6 & 200 & Blue & -1 & -1 & 1 & -1 & 1 & \\
\hline 7 & 30 & 20 & 6 & 300 & Red & -1 & -1 & 1 & 1 & -1 & \\
\hline 8 & 30 & 20 & 6 & 300 & Blue & -1 & -1 & 1 & 1 & 1 & \\
\hline 9 & 30 & 40 & 2 & 200 & Red & -1 & 1 & -1 & -1 & -1 & \\
\hline 10 & 30 & 40 & 2 & 200 & Blue & -1 & 1 & -1 & -1 & 1 & \\
\hline 11 & 30 & 40 & 2 & 300 & Red & -1 & 1 & -1 & 1 & -1 & \\
\hline 12 & 30 & 40 & 2 & 300 & Blue & -1 & 1 & -1 & 1 & 1 & \\
\hline 13 & 30 & 40 & 6 & 200 & Red & -1 & 1 & 1 & -1 & -1 & \\
\hline 14 & 30 & 40 & 6 & 200 & Blue & -1 & 1 & 1 & -1 & 1 & \\
\hline 15 & 30 & 40 & 6 & 300 & Red & -1 & 1 & 1 & 1 & -1 & \\
\hline 16 & 30 & 40 & 6 & 300 & Blue & -1 & 1 & 1 & 1 & 1 & \\
\hline 17 & 45 & 20 & 2 & 200 & Red & 1 & -1 & -1 & -1 & -1 & \\
\hline 18 & 45 & 20 & 2 & 200 & Blue & 1 & -1 & -1 & -1 & 1 & \\
\hline 19 & 45 & 20 & 2 & 300 & Red & 1 & -1 & -1 & 1 & -1 & \\
\hline 20 & 45 & 20 & 2 & 300 & Blue & 1 & -1 & -1 & 1 & 1 & \\
\hline 21 & 45 & 20 & 6 & 200 & Red & 1 & -1 & 1 & -1 & -1 & \\
\hline 22 & 45 & 20 & 6 & 200 & Blue & 1 & -1 & 1 & -1 & 1 & \\
\hline 23 & 45 & 20 & 6 & 300 & Red & 1 & -1 & 1 & 1 & -1 & \\
\hline 24 & 45 & 20 & 6 & 300 & Blue & 1 & -1 & 1 & 1 & 1 & \\
\hline 25 & 45 & 40 & 2 & 200 & Red & 1 & 1 & -1 & -1 & -1 & \\
\hline 26 & 45 & 40 & 2 & 200 & Blue & 1 & 1 & -1 & -1 & 1 & \\
\hline 27 & 45 & 40 & 2 & 300 & Red & 1 & 1 & -1 & 1 & -1 & \\
\hline 28 & 45 & 40 & 2 & 300 & Blue & 1 & 1 & -1 & 1 & 1 & \\
\hline 29 & 45 & 40 & 6 & 200 & Red & 1 & 1 & 1 & -1 & -1 & \\
\hline 30 & 45 & 40 & 6 & 200 & Blue & 1 & 1 & 1 & -1 & 1 & \\
\hline 31 & 45 & 40 & 6 & 300 & Red & 1 & 1 & 1 & 1 & -1 & \\
\hline 32 & 45 & 40 & 6 & 300 & Blue & 1 & 1 & 1 & 1 & 1 & \\
\hline 33 & 37.5 & 30 & 4 & 250 & Black & 0 & 0 & 0 & 0 & 0 & Center \\
\hline 34 & 56.5 & 55.1 & 8.7 & 223.1 & Blue & 2.5 & 2.5 & 2.4 & -0.5 & 1 & $\begin{array}{c}\text { Steepest } \\
\text { ascendent }\end{array}$ \\
\hline 35 & 72 & 75.8 & 12.8 & 191.3 & Blue & 4.6 & 4.6 & 4.4 & -1.2 & 2 & \\
\hline 36 & 86.2 & 94.8 & 16.5 & 156.6 & Blue & 6.5 & 6.5 & 6.3 & -1.9 & 3 & \\
\hline 37 & 99.7 & 112.9 & 20.2 & 120.6 & Blue & 8.3 & 8.3 & 8.1 & -2.6 & 4 & \\
\hline 38 & 112.7 & 130.5 & 23.7 & 83.8 & Blue & 10 & 10 & 9.9 & -3.3 & 5 & \\
\hline 39 & 37.5 & 30 & 4 & 250 & Black & 0 & 0 & 0 & 0 & 0 & $\begin{array}{l}\text { Optimum and } \\
\text { neighbourhood }\end{array}$ \\
\hline 40 & 45 & 40 & 6 & 200 & Blue & 1 & 1 & 1 & -1 & 1 & \\
\hline
\end{tabular}

${ }^{a}$ Red: polydimethylsiloxane (PDMS) of $100 \mu \mathrm{m}$; black: carboxen/polydimethylsiloxane (carboxen/PDMS) of $75 \mu$ m; blue: polydimethylsiloxane/ divinylbenzene (PDMS/DVB) of $65 \mu \mathrm{m}$. 
extraction of analytes through the separation technique that is being evaluated.

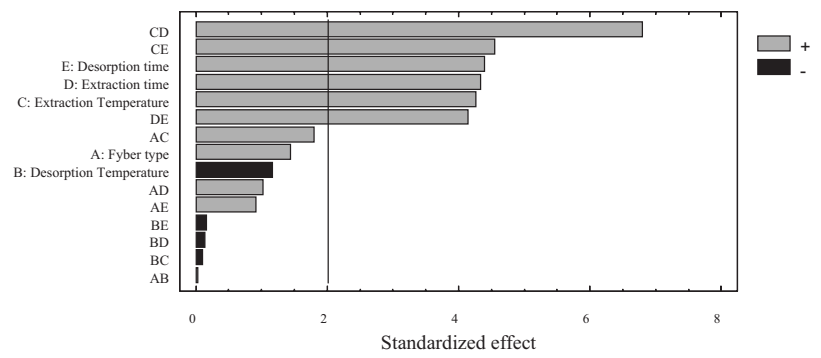

Figure 3. Standardized chart Pareto for the extraction efficiency's response in the HS-SPME technique for analyzing THMs in drinking water.

\section{Optimization of HS-SPME using response surface methodology}

The response surface representations (Figure 4, a-c), show that the interaction between extraction temperature and extraction time (which has the largest impact on the extraction technique, as shown in Figure 3) was stronger when both variables were at high levels in their respective values.

In other words, for a better extraction of the analytes of THMs in the separation and preconcentration technique, higher extraction temperature of $35^{\circ} \mathrm{C}$ and extraction times above 30 min should be used.
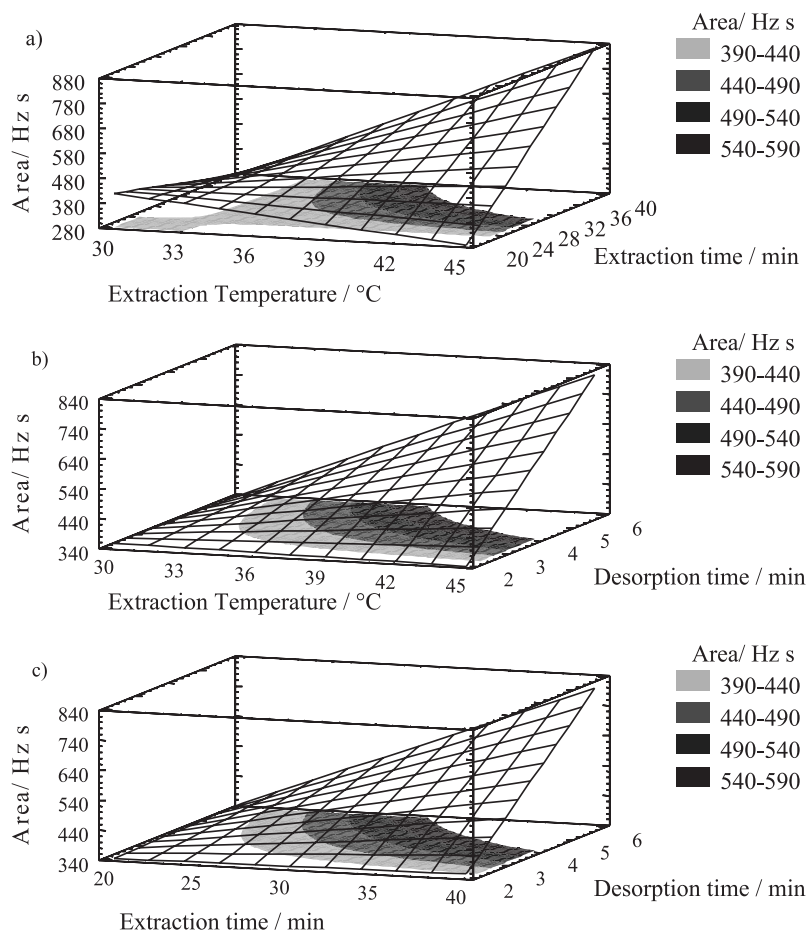

Figure 4. Estimated response surface for bromodichloromethane obtained with the composite design: a) extraction Temperature and extraction time; b) extraction Temperature and desorption time; c) extraction and desorption time.
However, as the HS-SPME process consists of sampling in the equilibrium established between the aqueous and vapor phases, to achieve the better and more reproducible values, and consequently the maximum extraction of the analytes, a study in depth was carried out. The experiment 39 (Table 3 and Figure 4, a-c) at $37.5^{\circ} \mathrm{C}$ as extraction temperature, $30 \mathrm{~min}$ extraction time, $4 \mathrm{~min}$ at the desorption time, $250{ }^{\circ} \mathrm{C}$ on the desorption temperature was selected as the best one. This coincides with the values established as a center in our experimental design. This is explained by recalling that the analytical technique study leads to equilibrium, and thus an increase in the values of the factors influencing it, does not alter the values. It is likely for this reason that the steepest ascendant way to reach the maximum efficiency by using this model (Table 3 ) will get the target with better extraction using higher levels than those set by the experimental design, but chemical equilibrium establish other more realistic conditions.

Comparison between different values of the levels for the control factors studied

Figure 5 shows the results obtained in the optimization of the parameters for the analysis of THM by HS-SPME. As can be seen, Figure 5 identifies the type of fiber CAR/ PDMS $(75 \mu \mathrm{m})$ as one that provides the best response of target compounds, which agrees with the findings in the design.

This behavior is due to the chemical characteristics of polarity of the fiber in question, since the dual component carboxen/polydimethyl-siloxane provides bipolarity and allows the selectivity for analytes of medium and low polarity, in contrast to the PDMS fiber that is selective for nonpolar compounds.

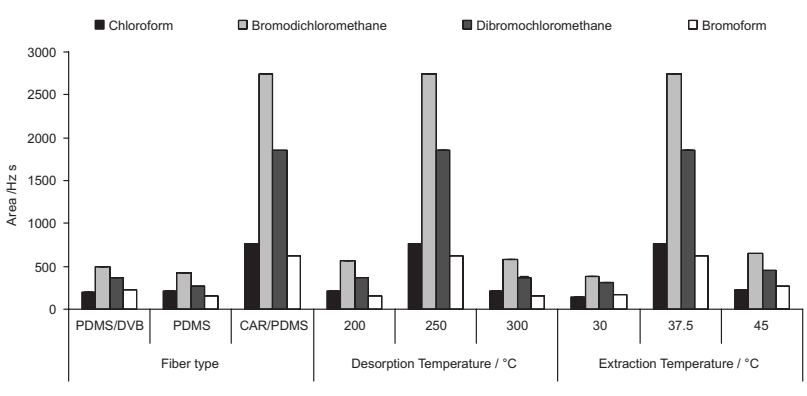

Figure 5. Extraction efficiency versus different control factors in HSSPME, at their best conditions and $30 \mathrm{~min}$ extraction time and $4 \mathrm{~min}$ desorption time.

Differences between fiber CAR/PDMS and PDMS/DVB are not very deep, because both contain the PDMS group, so that bipolar behavior is expected for both fibers, although the group divinylbenzene (DVB) gives a slightly higher degree 


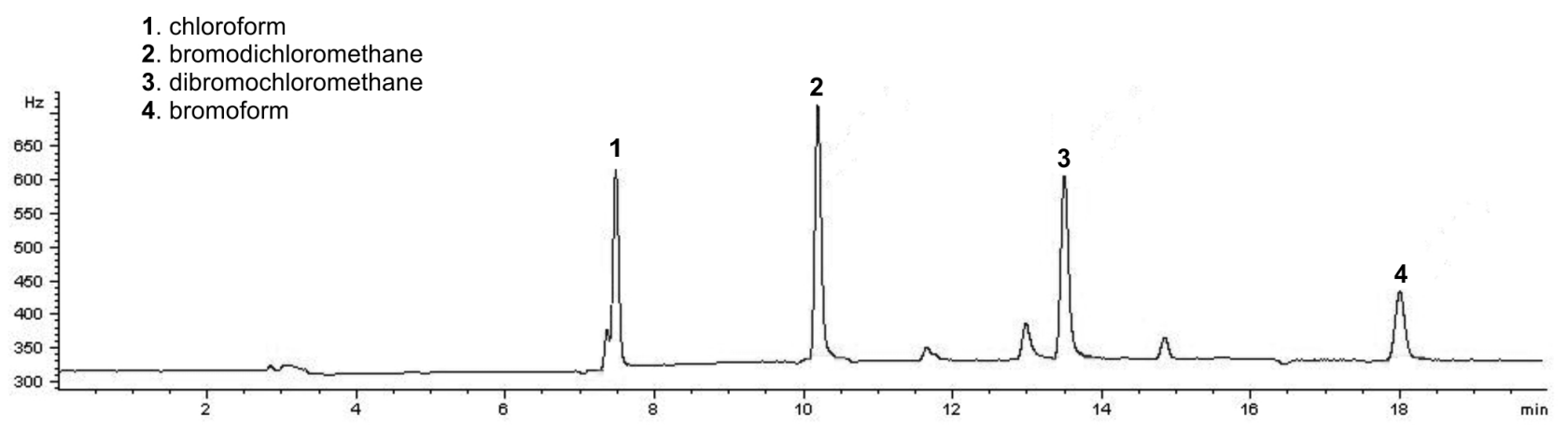

Figure 6. Chromatogram of a sample drinking water treatment plant "El Mirador" Viterbo-Caldas, Colombia under the best conditions of HS-SPME-GC$\mu \mathrm{ECD}$ (run 39 in the DOE).

of polarity. Therefore, to establish an order in terms of better extraction the order CAR/PDMS $\gg>$ PDMS/DVB $>$ PDMS can be mentioned. Other authors have reported that fiber CAR/PDMS provides better extraction of analytes. ${ }^{23,27,30,32,34}$ However, the versatility of the different types of fiber can also be found in the literature, where fiber PDMS/DVB showed better results for the extraction of THMs compounds ${ }^{35}$ and in a few exceptions, also PDMS fiber was proposed for the analysis of THMs by HS-SPME. ${ }^{33}$

Other variables were the desorption and extraction temperatures showing that at $250{ }^{\circ} \mathrm{C}$ as desorption temperature, the response is maximized, which coincides with James and co-workers ${ }^{36}$ (and Horng cited in reference 36) who indicated that the effect of temperature on the absorption of the analytes shows that at low temperatures, the ratio of diffusion is low and the time to reach equilibrium is longer. With an increase in temperature the distribution constant decreases, and as the absorption is generally an exothermic process, then the amount of analyte absorbed into the fiber decreases. For this reason, it was found that the desorption temperature better corresponds to $250{ }^{\circ} \mathrm{C}$, and other authors confirmed this as well by obtaining specific temperature or close to this value.

For the extraction temperature there was a more efficient response of $37.5^{\circ} \mathrm{C}$, being the central level in the DOE $30^{\circ} \mathrm{C}$ and $45^{\circ} \mathrm{C}$ (the lower and upper levels of the variable ), thus agreeing with those reported by other authors. ${ }^{23,27,35}$

In the evaluation of extraction and desorption times, the values were 30 and $4 \mathrm{~min}$, respectively, which in chemical terms is logical, due to the chemical equilibrium theory. These values represent better extraction, taking into account that the THMs compounds are low molecular weight and have low values of Henry's constant. ${ }^{27}$

\section{Analysis of drinking water samples}

The optimization of HS-SPME technique, through a composite $2^{5}$ factorial design and response surface methodology has been carried out to establish the operating factors that have the greatest impact for the better extraction trihalomethanes. Subsequent determination of THM in real water samples was done by gas chromatography $\mu \mathrm{ECD}$.

Figure 6 shows the chromatogram under the best conditions above mentioned for the five control factors, obtaining a good separation of THMs in terms of resolution and shape peak with a relative short run time (7.358 min for $\mathrm{CHCl}_{3} ; 10.183$ min for $\mathrm{CHCl}_{2} \mathrm{Br} ; 13.488 \mathrm{~min}$ for $\mathrm{CHClBr}_{2}$ and 18.008 for $\mathrm{CHBr}_{3}$ ).

\section{Conclusions}

Among the three fibers studied, (PDMS-100 $\mu \mathrm{m})$, (CAR/PDMS-75 $\mu \mathrm{m}$ ) and (PDMS/DVB-65 $\mu \mathrm{m})$, the CAR/PDMS of $75 \mu \mathrm{m}$ fiber was selected for the best efficiency extraction of the THMs compounds, based on its characteristics of polarity, since this fiber gives a bipolarity by having both polar and nonpolar group in its coating and taking into account that the compounds to be analyzed are moderately polar. The steepest ascendent path to optimization in the experimental design (Table 3) was found. For the evaluation of the factors that influence the HS-SPME technique, the highest incidence in the collection is composed by factors such as extraction temperature and extraction and desorption times, as well as high extraction time and high temperature extraction, high desorption time and high extraction temperature, high extraction time and high desorption time and high polarity of fiber type and high extraction time. The HS-SPME technique provides a great alternative to a phase extraction and preconcentration of analytes prior to determination by gas chromatography, as this technique gives high selectivity and sensitivity, is free of organic solvents, can be developed automatically and manipulation of the sample using this technique is minimal. 


\section{Acknowledgments}

The authors thanks to company Obras Sanitarias de Caldas EMPOCALDAS S.A. E.S.P., the Departments of Chemistry and Mathematics and the Vice-Rector for Research and Post Graduate of the University of Caldas.

\section{References}

1. U.S. EPA (United States Environmental Protection Agency), 1999a, EPA Guidance Manual - Alternative Disinfectants and Oxidants, EPA-815-R-99-014, U.S. EPA, Washington, DC, April 1999.

2. Rodríguez, J. M.; Interciencia 2007, 32, 11.

3. Zogorski, J. S.; Ivahnenko.T.; U.S. Geological Survey 2006, 13. <http://pubs.er.usgs.gov/publication/sir20065015>.

4. Rodrigues, P. M. S. M.; Esteves da Silva, J. C. G.; Antunes, M. C. G.; Anal. Chim. Acta 2007, 595, 266.

5. Gonzalez-Vila, F. J.; Lankes, U.; Ludemann, H. D.; J. Anal. Appl. Pyrolysis 2001, 58-59, 349.

6. Junkers, J.; Schmitt-Kopplin, P.; J. Chromatogr., A 2003, 998, 1 .

7. Rook, J. J.; Water Treatment Examination 1974, 23, 234. $<$ https://scifinder.cas.org.roble.unizar.es:9443/scifinder/view/ scifinder/scifinderExplore.jsf $>$.

8. Zhao, R. S.; Lao, W. J.; Xu, X. B.; Talanta 2004, 62,751.

9. US Environmental Protection Agency; EPA method 551.1, Rev. 1.0., Cincinnati, OH, 1995. <http://nlquery.epa.gov/epasearch/ epasearch?querytext $=$ method $+551.1 \&$ fld $=\&$ areaname $=\&$ ty peofsearch=epa\&areacontacts=http $\% 3 \mathrm{~A} \% 2 \mathrm{~F} \% 2 \mathrm{Fwww}$.epa gov\%2Fepahome\%2Fcomments.htm\&areasearchurl=\&result_ template=epafiles_default.xsl\&filter=sample4filt.hts $>$.

10. Golfinopoulos, S. K.; Lekas, T. D.; Nikolaou, A. D.; Chemosphere 2001, 45, 275.

11. Leivadara, S. V.; Nikolaou, A. D.; Lekkas, T. D.; Food Chem. 2008, 108, 277.

12. Nikolaou, A.; Desalination 2005, 176, 25.

13. Nikolaou, A. D.; Lekkas, T. D.; Golfinopoulos, S. K.; Kostopoulou, M. N.; Talanta 2002, 56, 717.

14. Caro, J.; Serrano, A.; Gallego, M.; J. Chromatogr., A 2007, 1138, 244.

15. Gallard, H.; Von Gunten, U.; Water Res. 2002, 36, 65.

16. Kuivinen, J.; Johnsson, H.; Water Res. 1999, 33, 1201.

17. Serrano, A.; Gallego, M.; J. Chromatogr., A 2007, 1154, 26.

18. Allonier, A.; Khalanski, M.; Bermond, A.; Camel, V.; Talanta 2000, 51, 467.
19. Campillo, N.; Viñas, P.; López-García, I.; Aguinaga, N.; Hernández-Córdoba, M.: J. Chromatogr., A 2004, 1035, 1.

20. Chen, T. C.; Her, G. R.; J. Chromatogr., A 2001, 927, 229.

21. Ekdahl, A.; Abrahamsson, K.; Anal. Chim. Acta 1997, 357, 197.

22. Kampioti, A. A.; Stephanou, E. G.; J. Chromatogr., A 1999 , 857, 217.

23. Lara-Gonzalo, A.; Sánchez-Uría, J. E.; Segovía-García, E.; Sanz-Medel, A.; Talanta 2008, 74, 1455.

24. Zoccolillo, L.; Amendola, L.; Cafaro, C.; Insogna, S.; J. Chromatogr., A 2005, 1077,181.

25. Zygmunt, B.; J. Chromatogr., A 1996, 725, 157.

26. Di Gioia, M. L.; Leggio, A.; Pera, A.; Liguori, A.; Chromatographia 2004, 60, 319.

27. Antoniou, C. V.; Koukouraki, E. E.; Diamadopoulos, E.; J. Chromatogr., A 2006, 1132, 310 .

28. Cancho, B.; Ventura, F.; Galceran, M. T.; J. Chromatogr. A 1999, 841, 197.

29. Chen, M.-L.; Mao, I.-F.; Hsu, C.-C.; Toxicol. Environ. Chem. 1997, 60, 39 .

30. Cho, D.-H.; Kong, S.-H.; Oh, S.-G.; Water Res. 2003, 37, 402.

31. Frazey, P. A.; Barkley, R. M. Sievers, R. E.; Anal. Chem. 1998, $70,638$.

32. Guimaraes, A. D.; Carvalho, J. J.; Goncalves, C.; Alpendurada, M. D.; Int. J. Environ. Anal. Chem. 2008, 88, 151.

33. Nakamura, S.; Daishima, S.; Anal. Chim. Acta 2005, 548, 79.

34. Rosero, M.; Aguirre, M.; Pezo, D.; Taborda, G.; Dussan, C.; Nerín, C.; Water, Air, Soil Pollut. 2011, 1. http://dx.doi. org/10.1007/s11270-011-0891-9

35. San Juan, P. M.; Carrillo, J. D.; Tena, M. T.; J. Chromatogr., A 2007, 1139, 27.

36. Stack, M. A.; Fitzgerald, G.; O'Connell, S.; James, K. J.; Chemosphere 2000, 41, 1821.

37. Gonzalez-Gago, A.; Marchante-Gayón, J. M.; García Alonso, J. I.; J. Anal. At. Spectrom. 2007, 22, 1138.

38. Batlle, R.; Sanchez, C.; Nerin, C.; Anal. Chem. 1999, 71, 2417.

39. Platikanov, S.; Tauler, R.; Rodrigues, P. M.; Antunes, M. C.; Pereira, D.; Environ. Sci. Pollut. Res. 2010, 17, 1389.

40. Salafranca, J.; Domeño, C.; Fernández, C.; Nerín, C.; Anal. Chim. Acta 2003, 477, 257.

41. Sun, A. D.; Chen, W.; Lin, T.; Xu, Q.; Clean - Soil, Air, Water 2010, 38, 353. 